\title{
Relationship between coping and subjective well-being of elderly from the interior of the Brazilian Northeast
}

\author{
Rafael Pereira Nunes ${ }^{1 *}$, Rômulo Lustosa Pimenteira de Melo², Edivan Gonçalves da Silva Júnior² \\ and Maria do Carmo Eulálio
}

\begin{abstract}
The objective of this study was to verify how the coping strategies, applied to health problems of the elderly, are related to the levels of Subjective Well-Being (SWB) in a cluster sample of 381 elderly people with an average age of 71.50 years $(\mathrm{SD}=8.0)$, mostly female $(73.4 \%)$. The following instruments were used: Mini-Mental State Examination, Problem Coping Mode Scale, Satisfaction with Life Scale, Positive and Negative Affect Schedule and demographic issues. The results indicated that, among all the coping strategies, the most used were the Religious Practices. The Focus on Problem explained positively and the Focus on Emotion explained negatively the SWB. Therefore, focus on the problem contributes positively to the psychosocial adaptation of the elderly to health problems.
\end{abstract}

Keywords: Coping styles, Subjective well-being, Elderly, Health

\section{Background}

The study of human aging has increased in recent years in Brazil, especially in the health area, mainly due to the growth of the elderly population (Valadares et al. 2013). In 2010, it was estimated that $11 \%$ of the Brazilian population was 60 years old or older (Camarano \& Kanso 2011). Based on the most recent demographic census, the Brazilian Institute of Geography and Statistics (IBGE, 2013) announced that the population over 60 years of age will more than double by 2060 , representing $26.7 \%$ of the Brazilian population.

The increase in the longevity of the Brazilian population has been associated with a greater prevalence of physical and psychological health problems. Studies that aim to assess salutogenic aspects of man are still recent (Scorsolini-Comin \& Santos 2012). In that sense, this study is interested in verifying how the elderly could maintain their levels of happiness, even when confronted with stressful events.

With regard to the scientific study of happiness, in this study, Subjective Well-Being (SWB) emerges. The concept

\footnotetext{
* Correspondence: rafaelrh10@hotmail.com

'Universidade Federal do Pará, Belém, Brazil

Full list of author information is available at the end of the article
}

of SWB emerges associated with the term successful old age and derives from the change in perspective of gerontology, which as from the 1960's stops considering old age and aging as a mere synonym of disease and inactivity, changing the focus to the aspects that further health (Cachioni \& Batistoni 2012).

In view of the different premises that support the scientific study of happiness, there are recurring disagreements on the concept and confusion between terms like "quality of life" and "health conditions". Nevertheless, there exists a consensus on its subjective assessment. SWB refers to how people feel and assess their lives, based on two components: cognitive SWB (cognitive assessment of satisfaction with life) and affective SWB (presence of positive affects and absence of negative affects) (Diener et al. 1999; Woyciekoski et al. 2012). One relevant point with regard to SWB refers to its contributions to the improvement of population health and longevity, as Diener and Chan (2011) appoint in a review and meta-analysis.

What the elderly public is concerned, studies (Jivraj et al. 2014; Rafnsson et al. 2015) indicate that the SWB scores can be higher in more long-living cohorts when compared to younger groups. Nevertheless, changing 
deriving from the advance of age, like decline in the health condition for example, widowhood and retirement, contribute as effects of wear of elderly people's well-being (Jivraj et al. 2014). In addition, it is observed that satisfaction with life (cognitive component) increases with age (Diener et al. 1999; Ordonez et al. 2011), while the intensity of affective experiences declines over the years (Diener et al. 1999; Kunzmann et al. 2000).

The factors related to physical health tend to affect the people's SWB (Woyciekoski et al. 2012, Scorsolini-Comin et al. 2013). The two domains (affective and cognitive) of the SWB can be influences by the biopsychosocial vulnerabilities that are enhanced with age (Neri et al. 2014). Nevertheless, despite these events, the elderly may still be able to maintain their levels of happiness.

That is the sense in which the question is raised about the best strategies to cope with the challenges deriving from the decline of physical health. The core theories regarding the SWB acknowledge that, among the main potentials of man, the ability to adapt to stressful conditions stands out. In the literature, this ability is better known as coping (Lima et al. 2012).

Coping, aka Problem Coping, comprises the cognitive and behavioral aspects used to administer internal and external requirements that are assessed as stressful (Folkman \& Moskowitz 2004). Studies appoint different coping strategies (Skinner et al. 2003; Tomás et al. 2012) but, in general, they can be classified in two categories according to their functions, defined by Lazarus and Folkman (1984) as focused on the problem and focused on the emotion. In the first case, efforts are focused on the situation that originated the burden in order to manage or solve it; the second case refers to an effort focused on the environment, to relieve the emotional tension deriving from certain requirements (Santos et al. 2013). In addition, in line with Seidl et al. (2001), in this study, beyond the problem and emotion focus, the coping based on Religious Practices/Fanciful Thoughts and on the Search for Social Support is assessed.

Studies have found evidence that the Problem-Focused Coping Strategies are associated with well-being in the elderly (Tomás et al. 2012), greater adherence to health treatments (Sousa et al. 2011) and positive affects in cancer patients undergoing radiotherapy (Paula Júnior \& Zanini 2011). Nevertheless, inconsistencies have been found as, sometimes, no correlations with health variables are found (Levasseur \& Couture 2015; Sousa et al. 2011).

The coping strategies figure among the main psychosocial resources to maintain the SWB (Faro 2013). In that sense, the objective in this study is to verify how the coping strategies applied to elderly people's health problems relate with the levels of SWB. It is expected that the problem focus, the strategies focused on religion and fanciful thoughts and the focus on social support positively explain the SWB.

\section{Method}

This study is part of a broader research entitled "Mental health profile of elderly in the city of Campina GrandePB", with a quantitative approach and ex-post facto design. Cluster sampling from the city of Campina Grande-PB was used. Forty-four census sectors were drafted (used as clusters), which are delimited by the IBGE and are considered as the smallest territorial unit with identifiable physical limits and appropriate dimensions to undertake research (IBGE 2011).

\section{Sample}

The minimum sample size estimated for the research was 381 , for a $5 \%$ sampling error and $\sigma=1.96$ (represents the $95 \%$ confidence interval). The establishment of this value was estimated based on the sample size needed to obtain a proportion of $50 \%$ for the occurrence of a certain characteristic of the elderly population (value at which the sampling size obtained in the highest possible for $p=0.50$ and $q=0.50)$. Considering a population of 42,817 elderly people (IBGE 2011), the formula for finite populations was used: $n=\sigma^{2}$. p.q.N/e $\mathrm{e}^{2} \cdot(\mathrm{N}-1)+\sigma^{2}$. p.q. Therefore, approximately nine elderly were collected per census sector.

In total, 381 male and female elderly accepted to participate in the research free of charge, aged 60 years or older, who reached the cut-off point established by the Mini-Mental State Examination (MMSE), assessed according to the participant's education level (Brucki et al. 2003). In this assessment, it was considered that the answers of elderly with cognitive problem scores could compromise the reliability of the tools to be applied. Thus, to comply with the psychometric requisites of the scales, attention, concentration and preserved reasoning skills are needed.

This research found a predominance of the female sex (73.4\%), with a mean age of 71.50 years $(\mathrm{SD}=8.00)$, most elderly being concentrated in the age range between 60 and 69 years $(44.4 \%)$. The majority is present or lives with a partner (44.1\%). As regards education, $53.3 \%$ declared having finished primary education. Most elderly self-declared Catholic (71.9\%), had their own home $(75.9 \%)$ and a monthly personal income of up to one minimum wage $(60.8 \%)$.

Elderly with a cognitive deficit were excluded; as well as patients with severe sequelae after Cerebrovascular Accident; patients with Parkinson's Disease in a severe or unstable stage; patients with severe hearing or sight impairments; and patients unable to participate due to severe illness. These criteria were necessary, considering that elderly people committed by these problems would face difficulties to answer the research questionnaires. 


\section{Tools}

The elderly answered a protocol consisting of a demographic questionnaire, the Mini-Mental State Examination (MMSE) (Folstein et al. 1975), the Problem Coping Mode Scale (PCMS) (Seidl et al. 2001), Satisfaction with Life Scale (SLS) (Diener et al. 1985) and the Positive and Negative Affect Schedule (Diener 1984).

To describe the demographic characteristics of the sample, demographic questions were applied, specifically: sex, age, education, marital status, religion, housing and income of the elderly.

The Mini-Mental State Examination (MMSE) is one of the most used cognitive screening tools in the world. Its validity has been evidenced in different studies. Folstein et al. (1975) found no statistically significant differences between the test and retest with a 28-day interval and a Pearson correlation coefficient of 0.83 . Lourenço and Veras (2006) found sensitivity, specificity, positive and negative predictive values of $80.8,65.3,44.7$ and $90.7 \%$, respectively. The same authors also weighted that education should constantly be considered for the adoption of cut-off points. The criteria from the FIBRA study (Frailty of Brazilian Elderly) were used: 17 (illiterate); 22 (education between 1 and 4 years); 24 (education between 5 and 8 years); 26 (9 or more years of education) (Brucki et al. 2003).

The Problem Coping Mode Scale (PCMS) (Seidl et al. 2001) reveals the coping strategies the subjects use when in stressful situations. It consists of 45 items, answered on a Likert scale, divided in four factors, which express how people cope with their problems. In the validation article, the four factors were extracted using the main axis method with orthogonal rotation and explained $25 \%$ of the shared variance: Problem-focused coping strategies $(\alpha=0.84)$; Emotion-focused coping strategies ( $\alpha=0.81)$; Religious practices/fanciful thinking $(\alpha=0.74)$ and search for social support $(\alpha=0.70)$.

The Satisfaction with Life Scale (SLS) was elaborated by Diener et al. (1985) to assess how satisfied people judge they are with their lives. It consists of five items and is answered on a Likert scale ranging from 1 (I completely disagree) to 7 (I completely agree). The scale was adapted and validated for the context of Paraíba by Albuquerque et al. (2010), in a sample of 342 elderly. In its validation, it showed a one-dimensional structure with an explained variance of $59.7 \%$ and Cronbach's Alpha of 0.84 .

The Positive and Negative Affect Schedule was formulated by Diener (1984) and consists of ten adjectives, being five positive and five negative, with alternative answers ranging between 1 (Nothing) and 7 (Extremely). The objective is to assess the intensity of the positive ("Happy", "Satisfied", "Amusing", "Optimistic" and "Joyful") and negative affects ("Depressed", "Frustrated",
"Mad", "Concerned" and "Unhappy"). The scale was validated by Albuquerque et al. (2010) for the context of Paraíba, in a sample of 342 elderly, explaining $40.88 \%$ (positive affects) and $18.18 \%$ (negative affects), respectively; with a Cronbrach's Alpha of 0.78 in each factor.

\section{Procedures}

The study started after the Committee for Ethics in Research at the Universidade Estadual da Paraíba (UEPB) gave its approval, registered under number 0655.0.133.000-11, in compliance with the standards of the National Health Council Resolution No. 196/96.

Ten psychology students from a public education institution in the state of Paraíba, properly trained and identified, visited the homes in the sectors drafted for the research, according to the geographical region mapped, working in pairs. If any elderly was present at the home visited, questions were asked about his willingness to participate in the research. After the acceptance and signing of the Free and Informed Consent Term (FICT), the data collection process started with the application of the tools. The first tool to be applied was the MMSE, followed by the scale of Coping strategies, with the researcher informing the participants that the questions dealt with how they were facing their health problems. The final two questionnaires were the SWB (Positive and Negative Affect Schedule and Satisfaction with life) and the demographic questionnaire.

\section{Data analysis}

The collected data were analyzed using the software PASW and AMOS (versions 18). Descriptive statistics were calculated for the demographic variables and for the PCMS, Satisfaction with Life scale and Positive and Negative Affect Schedule. In bivariate analyses, Student's $t$-test (sex and occupation with SWB), Pearson's correlation (between income and SWB) and ANOVA for repeated measures with Bonferroni's post-hoc test (used among the factors of the SWB). To verify the relation between the coping strategies and the SWB dimensions, multiple linear regression (using the stepwise method) was used to determine the predictive capacity of the coping strategies in each of the three subscales of subjective well-being. The four factors of the PCMS were included as independent variables and the SWB variables as dependent variables.

The software AMOS was used to confirm the factorial structure of the measures and thus top up the reliability of the results. Therefore, the following adjustment indicators were considered (Tabachnick \& Fidell 2013):

The index $\chi^{2} / \mathrm{df}$ (degrees of freedom). This is considered a subjective quality of adjustment. An index between two and three is recommended, accepting values 
up to five to indicate the fitness of the theoretical model to describe the data.

The Goodness-of-Fit Index (GFI) and the Adjusted Goodness-of-Fit Index (AGFI) are adjustment indicators that reflect the proportion of variance-covariance in the data explained by the model. The indices range between 0 and 1 . Values of 0.90 or higher are recommended.

The Comparative Fit Index (CFI) is an additional comparative index of adjustment to the model, with values closer to 1 expressing better adjustment. Commonly, values close to 0.90 are admitted as a reference of an adjusted model.

The Root-Mean-Square Error of Approximation (RMSEA) and its $90 \%$ confidence interval $(90 \% \mathrm{CI})$ are based on the residual values; high values indicate a nonadjusted model. Therefore, values between 0.05 and 0.08 are recommended, admitting up to 0.10 .

\section{Results}

These study results were distributed according to the precedence of what is related to the study objectives. Therefore, initially, the psychometric properties of the scales were verified; next, the data on the coping strategies and subjective well-being were described, followed by the correlations between the variables and, finally, the effects of the coping strategies on subjective well-being.

\section{Psychometric properties of the coping strategies,} satisfaction with life and positive and negative affects

Table 1 displays the data on the adjustment of the factorial structures of the scales used. The four factors of the coping strategy scale showed a fitness slightly below what the literature recommends $(\chi 2 / \mathrm{gl}=1.78, \mathrm{GFI}=0.87$, AGFI $=0.84 ;$ CFI $=0.81$ and $\mathrm{RMSEA}=0.091$ ). The AFC of Satisfaction with Life presented indices within recommended levels $(\chi 2 / \mathrm{df}=2.42, \quad \mathrm{GFI}=0.99$, AGFI 0.96; CFI $=0.98$ and RMSEA $=0.061)$; as well as the Positive and Negative Affects Scale $(\chi 2 / \mathrm{gl}=2.74, \mathrm{GFI}=0.95$, AGFI $=0.92$; $\mathrm{CFI}=0.95$ and RMSEA = 0.068). The scale factors presented the following Cronbach's alpha: Coping Strategies Focused on Problems $(\alpha=0.81)$, Coping
Strategies Focused on Emotion $(\alpha=0.79)$, Religious Practices/Fanciful Thinking $(\alpha=0.69)$ and Search for Social Support $(\alpha=0.59)$. Concerning the Satisfaction with Life Scale (SLS) Cronbach's alpha corresponded to 0.71. The Positive and Negative Affect Schedule (PANAS) showed an internal consistency coefficient of $\alpha=0.74$ for positive affects and $\alpha=0.72$ for the negative affects.

\section{Description of subjective well-being and coping strategies}

Among the coping strategies analyzed, the strategy Religious Practices and Fanciful Thinking presented a significantly higher weighted average $(M=3.99 ; S D=0.70)$, followed by Problem-Focused Coping $(M=3.80$; $S D=$ 0.66), Search for Social Support $(M=3.00 ; S D=0.87)$ and, with a lower average, Emotion-Focused Coping $(M=2.23 ; S D=0.61) \quad($ Table 1$)$. The Positive Affects showed a weighted average of $M=5.07 \quad(S D=1.10)$, Negative Affects $M=2.19(S D=1.10)$ and Satisfaction with life $M=5.58(S D=1.14)$ (Table 2).

\section{Demographic correlations}

Among the coping strategies, only Religious Practices/ Fanciful Thinking showed a significant difference in the sex variable, indicating that women $(M=4.08 ; D P=0.61)$ use this strategy more than men $(M=3.73 ; D P=0.86)$ $[t(379)=-4.40 ; p<0.001]$.

Also regarding sex, the data indicated greater intensity of negative affects experienced by women $(M=2.29$; $D P=1.15)$ than by men $(M=1.91 ; D P=0.90)$, a result significantly different from zero $t(379)=-2.93 ; p<0.01$. As to the satisfaction with life scores, men showed a higher average $(M=5.78 ; S D=0.94)$ than women $(M=5.51$; $S D=1.19)[t(379)=2.06 ; p<0.01]$ (Table 3$)$.

Concerning the correlations with the income, the results show a positive and significant correlation between personal income and positive affects $(r=0.15 ; p<0.01)$ and Satisfaction with Life $(r=0.10 ; p<0.05)$, as well as a negative correlation with negative affects $(r=-0.11 ; p<0.05)$ (Table 3).

Table 1 Indicators of adjustment of coping strategies measure, SLS and PANAS Scales

\begin{tabular}{|c|c|c|c|c|c|c|}
\hline & Models & $x^{2}(d f)$ & GFI & AGFI & $\mathrm{CFI}$ & RMSEA (90 \% Cl) \\
\hline \multirow[t]{2}{*}{ Coping strategies } & Four factors & 1595.1 & 0.87 & 0.84 & 0.81 & $0.091(0.089-0.094)$ \\
\hline & & 893 & & & & \\
\hline \multirow[t]{2}{*}{ SLS } & One factor & 12.1 & 0.99 & 0.96 & 0.98 & $0.061(0.016-0.106)$ \\
\hline & & 5 & & & & \\
\hline \multirow[t]{2}{*}{ PANAS } & Two factors & 87.9 & 0.95 & 0.92 & 0.95 & $0.068(0.051-0.085)$ \\
\hline & & 32 & & & & \\
\hline
\end{tabular}

Obs: SLS satisfaction with life scale, PANAS positive and negative affect schedule

$N=381 . X^{2}=$ chi-squared, $d f$ degrees of freedom, GFI goodness-of-fit index, AGFI adjusted goodness-of-fit index, CFI comparative fit index, $R M S E A$ root-meansquare error of approximation, $90 \% \mathrm{Cl} 90 \%$ Confidence Interval 
Table 2 Descriptive statistics of PCMS and SWB dimensions

\begin{tabular}{|c|c|c|c|c|}
\hline Dimension & Average & SD & $p$ & Partial squared Eta $\left(\eta^{2}\right)$ \\
\hline Problem focus & $3.80^{\mathrm{a}}$ & 0.66 & $<0.001$ & 0,858 \\
\hline Emotion focus & $2.23^{\mathrm{b}}$ & 0.61 & & \\
\hline Religious practices & $3.99^{c}$ & 0.70 & & \\
\hline Social support & $3.00^{d}$ & 0.87 & & \\
\hline Positive affects & 5.07 & 1.10 & -— & \\
\hline Negative affects & 2.19 & 1.10 & & \\
\hline Satisfaction with life & 5.58 & 1.14 & - - & \\
\hline
\end{tabular}

\section{Predictive capacity of coping strategies under SWB indices}

Table 4 shows the multiple regression results of the coping strategy variables under the SWB. The first model used satisfaction with life as the dependent variable $[F(3.38)=31.64 ; p<0.001]$. The first factor to enter the model was the strategy focused on emotion $(\beta=-0.35$; $p<0.001)$, followed by the problem-focused strategy $(\beta=0.27 ; p<0.001)$. This model explained $15 \%$ of the variation in the satisfaction with life. With positive affects as the dependent variable ( $2^{\text {nd }}$ model), the first strategy was the problem focus $(\beta=0.32 ; p<0.001)$, followed by the negative predictive power of the focus on emotion $(\beta=-0.26 ; p<0.001)$. The model was capable of explaining $13 \%$ of the total variation in the positive affects $[\mathrm{F}(1.378)=28.86 ; p<0.001]$. In the final model $\left(3^{\text {rd }}\right.$ model), using "negative affects" as the dependent variable, again only after the focus on emotion $(\beta=0.56 ; p<0.001)$ and the focus on the problem $(\beta=-0.21 ; p<0.001)$ entered the model. It is highlighted that, for the negative affects, the focus on emotion showed the greatest effect among all models tested, demonstrating that the people who focus on emotion are more subject to negative affects. The model explained $30 \%$ of the variance in the negative affects $[\mathrm{F}(1.378)=22.84 ; p<0.001]$.

\section{Discussion}

The results found in this study show that the most frequent strategies were the Religious Practices/Fanciful

Table 3 Comparison of affects and satisfaction with life between the sexes, and correlation between income

\begin{tabular}{lllll}
\hline & \multicolumn{1}{l}{ Sex } & & \multirow{2}{*}{ Income } \\
\cline { 2 - 4 } & Male & Female & & \\
SWB dimensions & $M(S D)$ & $M(S D)$ & $t(d f)$ & $r$ \\
\hline Positive affects & $5.15(1.13)$ & $5.04(1.09)$ & $0.91(379)$ & $0.15^{* *}$ \\
Negative affects & $1.91(0.90)$ & $2.29(1.15)$ & $-2.93^{* *}(379)$ & $-0.11^{*}$ \\
Satisfaction with life & $5.78(0.94)$ & $5.51(1.19)$ & $2.06^{* *}(379)$ & $0.10^{*}$ \\
\hline Obs.: $p<0.05^{*} ; P<0.01^{* *}$ & & & &
\end{tabular}

Thoughts and the Problem Focus. The average scores of Satisfaction with Life and Positive Affects reached high levels on the scale, as opposed to Negative Affects, appointing towards the maintenance of the SWB.

The analyses showed that Satisfaction with Life and Positive Affects increased in combination with the Problem Focus, and decreased with the Focus on Emotion. In addition, the negative affects increased together with the focus on emotion and the religious practices.

A lower SWB was observed in women and a higher presence in people with higher income levels. In women, the strategy focused on Religious Practices/Fanciful Thoughts was more frequent and higher averages were found for negative affects while, for men, higher satisfaction with life was obtained.

Concerning the SWB, the variance explained by demographic data thus far is not considerable (Diener 2009). Nevertheless, recent studies appoint that variables like the socioeconomic level and education are powerful predictors of subjective well-being in old age (Neri et al. 2014).

Guedea et al. (2006), in a study involving elderly people, found results that ratify the lesser satisfaction with life in women. Besides the lesser satisfaction in elderly receiving a benefit and higher satisfaction scores for people who receive and offer social support. Also regarding sex, Fernandes (2011) affirms not having found significant differences with regard to the investigated elderly's SWB. Nevertheless, higher dissatisfaction indices were observed among women, accompanied by severe and complete limitation in their physical health. The lower SWB indices observed in the female group are credited to the fact that women reach higher longevity and probably experience more health problems than men.

The favorable socioeconomic profile is highlighted in a longitudinal study (Rafnsson et al. 2015) as favoring higher levels of SWB in a group of older English adults, participants in the English Longitudinal Study of Ageing (ELSA). Woyciekoski et al. (2012), in a literature review, report that, among the determinants of SWB external to the individual, the socioeconomic difference is highlighted. In poor countries, in comparison with rich ones, the salary is more important for people's happiness. Nevertheless, the relation between income and SWB is mediated by cultural values like collectivism and individualism, so that, in case of an orientation by collective value, income is less related to SWB.

The problem focus showed to be the most effective strategy to top up the SWB. As highlighted by Paula Júnior \& Zanini (2011), this coping strategy is associated with better adaptation and with higher levels of resiliency and positive affects. But, especially in older populations, attention is needed to experiences like religiosity and spirituality, because they increase as age advances (Galicioli et al. 2012; Santos et. al. 2013). In this study, 
Table 4 Multiple linear regression between coping strategies and subjective well-being

\begin{tabular}{|c|c|c|c|c|c|}
\hline Models & Dependent variable & SBFM & B & $F(d f)$ & $R$ and $R^{2}$ \\
\hline \multirow[t]{2}{*}{$1^{\circ}$} & \multirow[t]{2}{*}{ Satisfaction with life } & Emotion focus & -0.35 & \multirow[t]{2}{*}{$33.727^{* * *}(2.378)$} & \multirow[t]{2}{*}{$R^{2}=0.15$} \\
\hline & & Problem focus & 0.27 & & \\
\hline \multirow[t]{2}{*}{$2^{\circ}$} & \multirow[t]{2}{*}{ Positive affects } & Problem focus & 0.32 & \multirow[t]{2}{*}{$29.12^{* * *}(2.378)$} & \multirow[t]{2}{*}{$R^{2}=0.13$} \\
\hline & & Emotion focus & -0.26 & & \\
\hline \multirow[t]{2}{*}{$3^{\circ}$} & \multirow[t]{2}{*}{ Negative affects } & Emotion focus & 0.56 & \multirow[t]{2}{*}{$82.773 * * *(2.378)$} & \multirow[t]{2}{*}{$R^{2}=0.30$} \\
\hline & & Problem focus & -0.21 & & \\
\hline
\end{tabular}

Obs.: $p<0.001^{* * *}$

the religious practices/fanciful thoughts were the most frequent among the participants, despite being positively associated with negative affects. The direction of the correlation is not a consensus in the literature. To give an example, Manglos (2013) highlighted the importance of religious experience for the SWB and its relation with the satisfaction with life of young adults. Seidl et al. (2001) consider that this may be due to the fact that the coping strategies often concentrate the focus on emotion.

The strategy "search for social support" was not correlated with the SWB indices. Nevertheless, perceived social support is a central element for successful aging (Vieira 2013). In view of difficulties, interpersonal relations are one of the main sources of support, functioning as an adaptive element (Scorsolini-Comin et al. 2013). Nevertheless, the achieve results suggest that there is no correlation between the problem-coping strategy based on social support and the participants' subjective wellbeing.

As expected, the problem focus confirmed its positive effect on the SWB. This coping modality is based on the mobilization of thoughts and attitudes, aiming to extinguish the stressful stimulus or reduce the feeling of bad adaptation to the stressful experience (Skinner \& Zimmer-Gembeck 2007). There are recurring studies in the literature that present the positive impact of the problem focus for the promotion and maintenance of well-being (Chang et al. 2007; Faro 2013; Paula Júnior \& Zanini 2011; Taylor \& Stanton 2007; Tomás et al. 2012).

Together with the problem focus, the emotion focus constituted the explanatory models of the SWB indices. As presented, however, the emotion focus has a negative function in the elderly's subjective well-being, as it is generally correlated with the greater experience of negative affects, lesser satisfaction with life and lesser quantity of positive affects. Levasseur and Couture (2015) investigated the coping strategies used by 82 elderly people to cope with limitations of aging and/or health problems. Moderate associations were found between the strategy focused on emotion, with lesser participation and quality of life in this group. Levasseur and Couture (2015) relate these results with negative psychological adjustment modes, which are associated with strategies focused on emotion. In a study involving cancer patients undergoing radiotherapy, it was observed that the use of avoiding strategies (focused on emotion) contributed to the increased experience of negative affect and reduction of these participants' reported positive affect (Paula Júnior \& Zanini 2011).

In a study involving Guedea et al. (2006), the greater satisfaction with life and the increase of positive affects by the elderly was linked with direct coping (problem focus), which refers to the use of cognitive and behavioral efforts to cope with the problem, or its positive perception. Problem avoidance, on the other hand, like what happens when one focuses on emotion, was associated with negative affects.

The search for external and internal factors that can increase the people's SWB figures among modern man's main concerns. Information obtained through studies on the SWB favor the growth in public policies that stimulate its increase and maintenance in the population, particularly for the elderly group, which is increasingly growing in society. In this respect, the observations by Diener and Chan (2011) should be highlighted, who defended that, in longevity, the years lived happily are significant, allied with the experience of better health.

\section{Conclusions}

This study appoints the importance of considering the three components of subjective well-being separately. They do not only differ in intensity, but also have distinct relations with the coping strategies. Through the indices of affects and satisfaction with life, the maintenance of the elderly's well-being was evidenced.

The emotion focus and the problem focus were the strategies most associated with the SWB, indicating that the problem focus is a resource to be used for the SWB of elderly people to reach higher levels. It should be highlighted that the emotion focus, although frequently used, negatively affects the SWB. The hypotheses that the strategies in religion/fanciful thoughts and in the search for social support represent a positive correlation with the SWB were not confirmed.

Future studies need to be developed to be able to longitudinally verify the relation between the coping strategies 
and the SWB. In that sense, these study results come with at least two important limitations that need to be considered. The first refers to the cross-sectional design, which hampers the establishment of a causal nexus between the variables; and the second is due to the fact that no specific health problem was considered in the elderly, as there may be distinct relations between the coping strategies and the SWB in function of some specific pathology. Hence, a good contribution to the assessment of SWB would be for future studies to compare, for example, the relations between these variables (Coping Strategies and SWB) and the presence of chronic and acute illnesses in elderly people.

\section{Competing interests}

This article is unpublished and original, it was not submitted to another journal for publication and meets all the ethical procedures by law. It has given permission for the editorial process. The authors declare that they have no competing interests.

\section{Authors' contributions}

RPN collaborated in the conceiving and manuscript analysis and interpretation of data; RLPM contributed to statistical analysis, interpretation and presentation of results; EGSJ contributed to the writing of the manuscript, discussion of data and critical review; MCE was responsible for the relevant critical review of the intellectual content and final approval of the version to be published.

\section{Acknowledgements}

The authors would like to thank the members of the Group of Study and Research on Aging and Health (GEPES) for the support provided in the collection and processing of data.

\section{Author details}

${ }^{1}$ Universidade Federal do Pará, Belém, Brazil. ${ }^{2}$ Universidade Estadual da Paraíba, Campina Grande, Brazil.

Received: 9 March 2016 Accepted: 7 April 2016

Published online: 22 April 2016

\section{References}

Albuquerque FJB, Sousa FM, Martins CR. Validação das escalas de satisfação com a vida e afetos para idosos. PSICO. 2010;41(1):85-92.

Brucki SMD, Nitrini R, Caramelli P. Bertoluci PHF, Okamoto IH. Sugestões para o uso do mini-exame do estado mental no Brasil. Arq Neuropsiquiatr. 2003; $61(3 B): 777-81$. doi:10.1590/50004-282X2003000500014.

Cachioni M, Batistoni SST. Bem-estar subjetivo e psicológico na velhice sob a perspectiva do conviver e do aprender. Revista Temática Kairós Gerontologia. 2012;15(7):09-22.

Camarano AA, Kanso S. Envelhecimento da população brasileira: uma contribuição demográfica. In: Freitas EV, Py L, editors. Tratado de Geriatria e Gerontologia. Rio de Janeiro: Guanabara Koogan; 2011. p. 58-73.

Chang EC, Sanna LV, Riley MM, Thournburg AM, Zumberg KM, Edwards MC Relations between problem-solving styles and psychological adjustment in young adults: Is stress a mediating variable? Personal Individ Diff. 2007;42(1): 135-44. doi:10.1016/j.paid.2006.06.011.

Diener E. Subjective well-being. Psychol Bull. 1984;95(3):542-75. doi:10.1037// 0033-2909.95.3.542.

Diener E. Subjective well-being. Sci Well Being Soc Indicat Res. 2009:37:11-58. doi:10.1007/978-90-481-2350-6_2.

Diener E, Chan MY. Happy people live longer: subjective well-being contributes to health and longevity. Appl Psychol Health Well Being. 2011;3(1):1-43. doi:10.1111/j.1758-0854.2010.01045.x.

Diener E, Emmons R, Larsen J, Griffin S. The satisfaction with life scale. J Pers Assess. 1985;49(1):71-5. doi:10.1207/s15327752jpa4901_13.

Diener E, Suh EM, Lucas RE, Smith HL. Subjective well- being: three decades of progress. Psychol Bull. 1999;125(2):276-302. doi:10.1037//0033-2909.125.2.276.
Faro A. Um modelo explicativo para o bem-estar subjetivo: estudo com mestrandos e doutorandos no Brasil. Psicologia Reflexão e Crítica. 2013;26(4): 654-62. doi:10.1590/S010279722013000400005.

Fernandes MCJ. Relação entre bem-estar subjetivo, saúde física e mental do idoso sob resposta social. Coimbra: Master's dissertation, Instituto Superior Miguel Torga; 2011.

Folkman S, Moskowitz JT. Coping: pitfalls and promise. Annu Rev Psychol. 2004; 55:745-74. doi:10.1146/annurev.psych.55.090902.141456.

Folstein M, Folstein S, Mchugh P. Mini-Mental state. A practical method for grading the cognitive status of patients for the clinician. J Psychiatr Res Ser. 1975;12:189-98.

Galicioli TGP, Lopes ESL, Rabelo DF. Superando a viúvez na velhice: o uso de estratégias de enfrentamento. Revista Temática Kairós Gerontologia. 2012; 15(4):225-37.

Guedea MA, Albuquerque FJ, Tróccoli BT, Noriega JA, Seabra MA, Guedea RL. Relação do bem-estar subjectivo, estratégias de enfrentamento e apoio social em Idosos. Psicologia Reflexão e Crítica. 2006;19(2):301-8. doi:10.1590/ S010279722006000200017.

Instituto Brasileiro de Geografia e Estatística. Base de informações do Censo Demográfico 2010: Resultados do Universo por setor censitário. Rio de Janeiro: Autor; 2011.

Instituto Brasileiro de Geografia e Estatística. Projeção da população do Brasil por sexo e idade para o período 2000/2060. Rio de Janeiro: Autor; 2013.

Jivraj S, Nazroo J, Vanhoutte B, Chandola T. Aging and subjective well-being in later life. J Gerontol Ser B Psychol Sci Soc Sci. 2014;69(6):1-12. doi:10.1093/ geronb/gbu006.

Kunzmann U, Little T, Smith J. Is age-related stability of subjective well-being a paradox? Cross-sectional and longitudinal evidence from Berlin Aging Study. Psychol Aging. 2000;15(3):511-26. doi:10.1037//0882-7974.15.3.511.

Lazarus RS, Folkman S. Stress, appraisal and coping. New York: Springer; 1984

Levasseur M, Couture M. Coping strategies associated with participation and quality of life in older adults. Can J Occup Ther. 2015;82(1):44-53. doi:10.1177/0008417414552188.

Lima MG, Barros MBA, Alves MCGP. Sentimento de felicidade em idosos: uma abordagem epidemiológica, ISA-Camp 2008. Cad Saude Publica. 2012;28(12): 2280-92. doi:10.1590/50102-311X2012001400007.

Lourenço RA, Veras RP. Mini-exame do estado mental: características psicométricas em idosos ambulatoriais. Rev Saude Publica. 2006;40(4):712-9. doi:10.1590/S0034-89102006000500023.

Manglos ND. Faith pinnacle moments: stress, miraculous experiences, and life satisfaction in young adulthood. Sociol Religion. 2013;74(2):176-98. doi:10.1093/socrel/srs071.

Neri AL, Eulálio M, do C, Cabral BE. Bem-estar indicado por satisfação, afetos positivos e negativos e senso de ajustamento pessoal. In: Neri AL, editor. Fragilidade e qualidade de vida na velhice. São Paulo: Alínea; 2014. p. 321-39.

Ordonez TN, Lima-Silva TB, Cachioni M. Subjective and psychological well-being of students of a university of the third age: benefits of continuing education for psychological adjustment in the elderly. Dement Neuropsychol. 2011;5(3):216-25.

Paula Júnior W, Zanini DS. Estratégias de coping de pacientes oncológicos em tratamento radioterápico. Psicologia Teoria e Pesquisa. 2011;27(4):491-7. doi:10.1590/S0102-37722011000400013.

Rafnsson SB, Shankar A, Steptoe A. Longitudinal influences of social network characteristics on subjective well-being of older adults: findings from the ELSA study. J Aging Health. 2015;27(5):919-34. doi:10.1177/ 0898264315572111.

Santos WJ, Giacomin KC, Pereira JK, Firmo JOA. Enfrentamento da incapacidade funcional por idosos por meio de crenças religiosas. Cien Saude Colet. 2013; 18(8):2319-28. doi:10.1590/S1413-81232013000800016.

Scorsolini-Comin F, Santos MA. A medida positiva dos afetos: bem-estar subjetivo em pessoas casadas. Psicologia Reflexão e Crítica. 2012;25(1):11-20. doi:10.1590/S0102-79722012000100003.

Scorsolini-Comin F, Fontaine AMGV, Koller SH, Santos MA. From authentic happiness to well-being: the flourishing of positive psychology. Psicologia Reflexão e Crítica. 2013;26(4):663-70. doi:10.1590/5010279722013000400006.

Seidl EMF, Troccoli BT, Zannon CMLC. Análise fatorial de uma medida de estratégias de enfrentamento. Psicologia Teoria e Pesquisa. 2001;17(3):225-34. doi:10.1590/ S0102-37722001000300004.

Skinner EA, Zimmer-Gembeck MJ. The development of coping. Annu Rev Psychol. 2007;58:119-44. 
Skinner EA, Edger K, Altman J, Sherwood H. Searching for the structure of coping: a review and critique of category systems for classifying ways of coping. Psychol Bull. 2003;129(2):216-69.

Sousa MRG, Landeiro MJL, Pires R, Santos C. Coping e Adesão ao regime Terapêutico, Revista de Enfermagem Referência, serll|(4). 2011. p. 151-60.

Tabachnick BG, Fidell LS. Using multivariate statistics. 6th ed. Boston: Allyn and Bacon; 2013

Taylor SE, Stanton AL. Coping resources, coping processes, and mental health. Annu Rev Clin Psychol. 2007;3:377-401.

Tomás JM, Sancho P, Melendez JC, Mayordomo T. Resilience and coping as predictors of general well-being in the elderly: a structural equation modeling approach. Aging Ment Health. 2012;16(3):317-26. doi:10.1080/ 13607863.2011 .615737$.

Valadares MO, Vianna LG, Moraes CF. A temática do envelhecimento humano nos grupos de pesquisa do Brasil. Revista Kairós Gerontologia. 2013;16(2):117-28.

Vieira LAM. Envolvimento e suporte social percebidos na velhice: dados do estudo Fibra, polo Unicamp. São Paulo: Master's dissertation, Faculdade de Ciências Médicas, Universidade Estadual de Campinas; 2013.

Woyciekoski C, Stenert F, Hutz CS. Determinantes do bem-estar subjetivo. PSICO. 2012;43(3):280-8.

\section{Submit your manuscript to a SpringerOpen ${ }^{\circ}$ journal and benefit from:}

- Convenient online submission

- Rigorous peer review

- Immediate publication on acceptance

- Open access: articles freely available online

High visibility within the field

- Retaining the copyright to your article

Submit your next manuscript at $\gg$ springeropen.com 